\title{
"The determinants of capital structure in coal mining industry on the Indonesia Stock Exchange"
}

\begin{tabular}{|c|c|}
\hline AUTHORS & $\begin{array}{l}\text { Sutomo Sutomo } \\
\text { Sugeng Wahyudi (D http://orcid.org/0000-0003-2889-7123 } \\
\text { Irene Rini Demi Pangestuti (D http://orcid.org/0000-0003-3008-0972 } \\
\text { Harjum Muharam (D https://orcid.org/0000-0002-4627-9997 }\end{array}$ \\
\hline ARTICLE INFO & $\begin{array}{l}\text { Sutomo Sutomo, Sugeng Wahyudi, Irene Rini Demi Pangestuti and Harjum } \\
\text { Muharam (2020). The determinants of capital structure in coal mining industry on } \\
\text { the Indonesia Stock Exchange. Investment Management and Financial } \\
\text { Innovations, 17(1), 165-174. doi:10.21511/imfi.17(1).2020.15 }\end{array}$ \\
\hline DOI & http://dx.doi.org/10.21511/imfi.17(1).2020.15 \\
\hline RELEASED ON & Tuesday, 17 March 2020 \\
\hline RECEIVED ON & Tuesday, 13 August 2019 \\
\hline ACCEPTED ON & Friday, 22 November 2019 \\
\hline LICENSE & $\begin{array}{l}(c) E Y \\
\text { This work is licensed under a Creative Commons Attribution } 4.0 \text { International } \\
\text { License }\end{array}$ \\
\hline JOURNAL & "Investment Management and Financial Innovations" \\
\hline ISSN PRINT & $1810-4967$ \\
\hline ISSN ONLINE & $1812-9358$ \\
\hline PUBLISHER & LLC "Consulting Publishing Company "Business Perspectives" \\
\hline FOUNDER & LLC "Consulting Publishing Company "Business Perspectives" \\
\hline
\end{tabular}



60

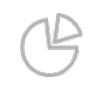

NUMBER OF FIGURES

0

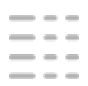

NUMBER OF TABLES

5

(C) The author(s) 2021. This publication is an open access article. 


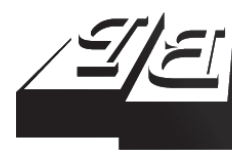

\section{BUSINESS PERSPECTIVES}

LLC "CPC "Business Perspectives" Hryhorii Skovoroda lane, 10, Sumy, 40022, Ukraine www.businessperspectives.org
Received on: $13^{\text {th }}$ of August, 2019 Accepted on: 22 $2^{\text {nd }}$ of November, 2019 Published on: 17th of March, 2020

(c) Sutomo Sutomo, Sugeng Wahyudi, Irene Rini Demi Pangestuti, Harjum Muharam, 2020

Sutomo Sutomo, Ph.D. Student, Doctoral Program in Economics, Faculty of Economics and Business, Universitas Diponegoro, Indonesia.

Sugeng Wahyudi, Professor, Department of Management, Faculty of Economics and Business, Universitas Diponegoro, Indonesia.

Irene Rini Demi Pangestuti, Assistant Professor, Department of Management Faculty of Economics and Business, Universitas Diponegoro, Indonesia.

Harjum Muharam, Associate Professor, Department of Management, Faculty of Economics and Business, Universitas Diponegoro, Indonesia.
This is an Open Access article, distributed under the terms of the Creative Commons Attribution 4.0 International license, which permits unrestricted re-use, distribution, and reproduction in any medium, provided the original work is properly cited.

Conflict of interest statement: Author(s) reported no conflict of interest
Sutomo Sutomo (Indonesia), Sugeng Wahyudi (Indonesia),

Irene Rini Demi Pangestuti (Indonesia), Harjum Muharam (Indonesia)

\section{THE DETERMINANTS OF CAPITAL STRUCTURE IN COAL MINING INDUSTRY ON THE INDONESIA STOCK EXCHANGE}

\begin{abstract}
This study aims to examine the effect of several variables such as profitability, firm size, asset structure, and commodity price (coal) on the capital structure with the debt to equity ratio (DER) as a proxy in the coal mining companies listed on the Indonesian capital market (i.e., the Indonesia Stock Exchange (IDX). The different results of previous studies related to the effect of some independent variables such as the firm size, profitability, asset structure, and dividend policy, such as dividend payout ratio to the DER, yield the research gaps that require further research. Data in this research were taken from the official public listed company's annual reports on the IDX website. By employing the multiple regression techniques, this study found that only profitability and asset structure significantly affect the capital structure (proxied by DER). The ef fect of profitability was negative, while the effect of asset structure was positive. Based on these results, the managers may start considering re-balancing the use of external funds if the profitability level increases. Further, they also need to maintain the company's asset structure and balance its' fixed assets so that the capital structure is well maintained. In general, the findings supported the pecking order theory.
\end{abstract}

\section{Keywords} capital structure, profitability, asset structure, mining companies, the Indonesia Stock Exchange (IDX), debt to equity ratio (DER)

\section{JEL Classification G10, G30}

\section{INTRODUCTION}

Competition in the increasingly hard business and economic world has made companies trying to increase their value. The business development of the companies will always require additional funds or capital. These funds can be obtained from various sources, namely from internal and external sources or through the use of debt. The company should also consider the use of external capital in the form of debt.

Errors in determining the capital structure will have a broad impact, especially if the company is using a huge amount of debt, resulting in the fixed burden that must be borne by the company is even greater (Kesuma, 2009). In relation to capital structure, there are several main theories. Some of the most notable theories are the trade-off theory and the Modigliani-Miller model. The trade-off theory suggests that a company will determine the level of its capital structure to a one that they want to achieve all the time (Brigham \& Houston, 2012). Companies tend to try to balance the benefits and costs that might arise from the debt with bankruptcy costs and agency costs in a capital structure. Hermuningsih (2013) found that a company manager could choose using debt ratios to increase the company's value. Meanwhile, the Modigliani-Miller model suggests that companies will be able to increase their value by using debt, and one of the reasons is the taxa- 
tion aspect (Margaretha \& Rizki, 2010). In addition to these theories, capital structure theory states that the company's funding policy to determine the capital structure aims to obtain optimal corporate value (Baker \& Wurgler, 2002; Handriani \& Robiyanto, 2018b; Hermuningsih, 2013).

Various studies found that there were many factors that could affect the company's capital structure as proxied by the debt to equity ratio (DER). The DER as a proxy for capital structure had been used in the researches by Gómez, Castro, and Ortega (2016), Handoo and Sharma (2014), Handriani and Robiyanto (2018a), Karadeniz, Kandir, Balcilar, and Onal (2009), Michalski, Blendinger, Rozsa, Cierniak-Emerych, Svidronova, Buleca, and Bulsara (2018), Nijenhuis (2013), Onofrei, Tudose, Durdureanu, and Anton (2015), Suarez (2016). In general, these studies used some independent variables, i.e., profitability, firm size, and asset structure as the variables that could affect the DER.

Hermuningsih (2013) performed a study that scrutinized the capital structure using the profitability variable and found the negative influence of profitability on the capital structure. The research used samples from various industries listed on the IDX. The results of the studies by Haron, K. Ibrahim, Nor, and I. Ibrahim (2013), Nnadi (2016), Onofrei, Tudose, Durdureanu, and Anton (2015), Sahabuddin (2017) also showed similar results. However, Margaretha and Rizki (2010) who used samples from the manufacturing sector listed on the IDX found different results. They found the positive influence of profitability on the capital structure. This is also supported by the results of Eviani (2015) who also used samples from various industries listed on the IDX.

Margaretha and Rizki (2010) also examined the effect of firm size on capital structure and found the positive influence firm size on the capital structure. The same was found by Murhadi (2011) on the Indonesia Stock Exchange, Eriotis, Vasiliou, and Ventoura-Neokosmidi (2007) in Turkey, Haron, Ibrahim, Nor, and Ibrahim (2013) in Thailand, and Nnadi (2016) in Nigeria. Suarez (2016) also found consistent results. However, Abor (2008) who conducted a study in Ghana found different results where company size negatively affected the short-term structure. Onofrei et al. (2015) and Handoo and Sharma (2014) also found the negative influence of firm size on the capital structure.

Eviani (2015) conducted a study that scrutinized the factors that could affect the capital structure of the manufacturing sector in the IDX by using asset structure as one of the independent variables affecting the capital structure. Eviani (2015) found no significant effect of asset structure on capital structure. This is also supported by the research results by Kesuma (2009), Nugroho (2006), Suarez (2016). However, different results were also found by Abor (2008) who examined the effect of asset structure on the companies' capital structure in Ghana. He found that asset structure had a significant and negative effect on capital structure. This is also supported by the results of Onofrei et al. (2015) and Nhung, Lien, and Hang (2017). Besides, Handoo and Sharma (2014) and Nnadi (2016) revealed the positive effect of asset structure on the capital structure.

The different results of previous studies related to the influence of variable profitability, firm size, asset structure, and dividend payout ratio to the DER resulted in research gaps that require further research. Previous researches were also performed in various industries and only focused on manufacturing industries. Besides, they did not examine the influence of external variables such as commodity prices or other external variables. Whereas, external variables, according to Nhung, Lien, and Hang (2017), for example, commodity prices such as coal prices for coal mining companies, could influence the capital structure and even the yields (Handriani \& Robiyanto, 2018a). The higher the commodity prices, the greater the company's profit will be. This results in greater internal funding compared to the external funding in the form of debt. Thus, the capital structure (DER) will be smaller. According to Abdur Rouf (2015), Dananti, Cahjono, and Mujiyono (2018), Uzliawati, Yuliana, Januarsi, and Santoso (2018), the debt to equity ratio (DER) is a good measurement to the capital structure; hence, this study employs the DER as a proxy of capital structure. 
Despite many similar studies regarding the capital structure in the ASEAN region, to the best of authors' knowledge, studies that employ samples taken from coal industry are very rare. Therefore, this study will focus on the effects of some independent variables, i.e., the asset structure, profitability, company size, and commodity prices (coal) to the debt to equity ratio in one industry, namely the coal mining industry. Coal mining companies were involved as this sector was considered to have considerable and complex risks (Fatoni, Paramu, \& Utami, 2013).

\section{LITERATURE REVIEW AND HYPOTHESES DEVELOPMENT}

Determinants of the capital structure still attract researchers' attention in the financial area to scrutinize, since Modigliani and Miller (1958) introduced the proposition of capital structure. Since then, some theories regarding the capital structure flourished. Kumar, Colombage, and Rao (2017) even stated that financial decision is very important for the firm's welfare. Among those theories were the trade-off theory and the pecking order theory. Trade-off theory was developed by Kraus and Litzenberger (1973), this theory argued that companies face higher financial risk when obtaining tax benefits from debt and that optimal capital structure can be achieved when the current value margin of the tax shield equals the present value margin of the cost of financial difficulties from additional debt.

The implication is that growing and profitable companies with low bankruptcy potential need to use more debt, and capital funding may be the best choice for riskier and unprofitable companies. But for companies with high potential for bankruptcy, if they do the same thing, they will be riskier to default or go bankrupt. However, this theory cannot explain why the most profitable companies borrow less and why companies have different capital structures, even though the tax rates are the same. While the pecking order theory was vinitiated by Stiglitz (1973) and enhanced by Myers and Majluf (1984) who found that companies sometimes prefer internal funding over external funding and prefer debt over capital when the internal funding is insufficient. The internal funding comes from retained earnings, where the latter will lead to lower level of debt that the company uses (Maneerattanarungrot \& Donkwa, 2018; Popovic \& Paunovic, 2018). Baker and Wurgler
(2002) find that low-leverage firms tend to be those that raised funds when their valuations were high, and, conversely, high-leverage firms tend to be those that raised funds when their valuations were low. Regarding this, Chirinko and Singha $(2000$, p. 418) stated that "The central friction in the pecking order model of capital structure is the asymmetric information between managers and less-informed outside investors." This statement shows that the pecking order theory is related with the asymmetric information theory.

According to Hang, Geyer-Klingeberg, Rathgeber, and Stöckl (2018), some variables will be affecting the capital structure differently based on some underlying theories, i.e., under the pecking order theory, firm size and profitability will have a negative effect on capital structure, while under the trade-off theory, those variables will have a positive effect. Based on the pecking order theory, companies with high profitability will tend to use funding through internal sources, namely using profits rather than debt when they need funding. Thus, the increased profitability will reduce the company's debt ratio. It can be concluded that profitability has a negative effect on capital structure. This is in line with the researches by Al-Ani and Al-Amri (2015), Dhingra and Dev (2016), Haron et al. (2013), Hermuningsih (2013), Nijenhuis (2013), Nnadi (2016), Serghiescu and Văidean (2014) who concluded that profitability had a negative effect on capital structure. Based on this reason, the first hypothesis that can be proposed is as follows:

\section{H1: Profitability has a negative effect on capital structure.}

The larger the firm size, the easier it will be for the company to get an external loan, both in the form of debt and share capital. Trade-off theory introduced by Kraus and Litzenberger (1973) is the one that provides the sign of the relationship between size and capital structure. It is because general- 
ly large companies have a pretty good reputation in the public perspective (Ernayani \& Robiyanto, 2016). Meanwhile, small companies have limited access to capital, especially through the capital market, which makes them unable to involve third parties as their partners. In addition, small companies with low cash inflows will find it more difficult to obtain debt because creditors consider it is riskier compared to large companies. Therefore, it can be concluded that the larger the firm size, the higher the capital structure. Empirically, this has been proven by Eriotis, Vasiliou, and VentouraNeokosmidi (2007), Kayedi, Ghahramanizady, and Jafarzadeh (2013), Murhadi (2011), Nnadi (2016), Utomo, Wahyudi, Muharam, and Taolin (2018). Based on this reason, the second hypothesis that can be proposed is as follows:

H2: Company's size has a positive effect on capital structure.

Asset structure is one of the important factors in the capital structure. When a company faces financial difficulties in repaying its obligations, the tangible assets or fixed assets owned by the company can be used as collateral for external parties who can provide loans. In line with the trade-off theory, companies with large assets will have a larger DER because they have assets as part of their collateral. They will also be able to obtain large amounts of debt because they are expected to be better in accessing the external fund sources compared to small companies. Companies also can use fixed assets as collateral (Handriani \& Robiyanto, 2019; Sartono, 2001), which, according to the agency cost theory, will lead to the conflict between management and shareholders. According to Joni and Lina (2010), procurement for fixed assets requires substantial funds and could cause additional debt burden for the company. Thus, it is not surprising that the ownership of large fixed assets is often followed by a large amount of debt. Empirically, this has also been proven by Handoo and Sharma (2014), Karadeniz, Kandir, Balcilar, and Onal (2009), Nhung et al. (2017), Nnadi (2016) who found the positive effect of asset structure on the capital structure. In this study, the asset structure was measured by the proportion of fixed assets toward total assets. Based on this reason, the following third hypothesis is formulated:
H3: Asset structure has a positive effect on capital structure.

Several previous types of research showed that commodity prices could have a positive effect on company returns. For example, Hersugondo, Robiyanto, Wahyudi, and Muharam (2015), Putra and Robiyanto (2019), Robiyanto (2018a, 2018b, 2018c) found that the increased in commodities could actually increase the stock returns. In relation to the capital structure, the price of this commodity would encourage the company to seek funding (Kurronen, 2018). Therefore, it could increase its production capacity and provide greater results. Nhung et al. (2017) also suggested that the type of industry would affect the capital structure. In the industries that depend on commodity prices, it was found that the higher the price of commodities, the higher the capital structure would be. Kurronen (2018) stated that "the trade-off theory argues that firms find the right balance between equity and debt to maximize firm value." The costs and benefits of borrowing thus affect the optimal capital structure. When the commodity price is high, a company will try to boost the sales in order to maximize the firm value by using both internal and external sources. When the commodity price is high, the company encourages to borrow more because of low probability of financial distress. This conforms with the signaling theory. This is also supported by Enakirerhi and Chijuka (2016), Eviani (2015), Haryanto (2016), Huang and Ritter (2004). For this study specifically examines coal mining sector companies, the higher coal price will encourage coal mining companies to borrow more funds. The following is the fourth hypothesis that can be formulated:

\section{H4: Coal prices have a positive effect on the capi- tal structure.}

\section{METHOD}

The population used in this study were all companies in the coal mining sector that had been listed on the Indonesia Stock Exchange since 2011. Since 2011, there had been 22 coal mining companies listed on the IDX. The sampling technique used in this study is the purposive sampling with the following criteria: 1) the coal mining companies should be listed on the IDX, and 2) the companies did not have com- 
Table 1. Operational variable definition

\begin{tabular}{|c|c|c|c|c|}
\hline & & & & Source: Developed for this rese \\
\hline Type of variable & Proxy & Scale & Variable measurement & Source \\
\hline Dependent & Debt to equity ratio & Ratio & $\begin{array}{c}\text { (Total liabilities/total equity) } \\
100 \%\end{array}$ & Annual report \\
\hline Independent & Return on asset & Ratio & (Net income/total asset) $* 100 \%$ & Annual report \\
\hline Independent & Asset structure & Ratio & $\begin{array}{c}\text { (Fixed assets/total assets) * } \\
100 \%\end{array}$ & Annual report \\
\hline Independent & Total asset (Size) & Ratio & $\operatorname{Ln}($ Size) & Annual report \\
\hline Independent & Coal price & Ratio & Ln (Price) & $\begin{array}{l}\text { https://www.indexmundi.com/ } \\
\text { commodities/ }\end{array}$ \\
\hline
\end{tabular}

plete data related to the variables used in the study and the data were not consistent in the Indonesia Stock Exchange in 2012-2018. From the criteria proposed earlier, 15 companies were obtained with a 7-year study period, which resulted in 105 observations. According to Park (2011), the panel data used in this study were categorized as balanced panel data and do not deal with both too small $N$ (Type I error) and too large $N$ (Type II error) problems matter. The number of observations in this study also could deal with minimum observation size for panel data, according to Santos and Barrios (2011).

The number of observations met the criteria suggested by Hair, Black, Babin, and Anderson (2009), which is a 10-times rule. Kock $(2018$, p. 4), Kock and Hadaya (2018, p. 228) stated that this assumption "builds on the assumption that the sample size should be greater than 10 times the maximum number of inner or outer model links pointing at any latent variable in the model." This research used five variables, so based on this rule, the minimum observation size is 50 .

The data needed in this study were the financial statements of the coal mining companies listed on the IDX in the period of 2012-2018. These data were obtained from the IDX official website. The data analysis method used was multiple regression analysis. Prior to the multiple regression analysis, classical assumption tests such as data normality test by using Kolmogorov-Smirnov statistics, heteroscedasticity test by using Glejser test, autocorrelation test by using Durbin-Watson Statistic, and multicollinearity test by using Variance Inflation Factor (VIF) were performed.

In order to apply the best model for panel data, some tests such as Chow test and Hausman test are necessary.

\section{RESULTS AND DISCUSSION}

\subsection{Classical assumption test results}

Before the regression analysis out, the classical assumption test was performed. The classical assumption test results are shown in Table 2 to Table 5. The residual values normality test was conducted by using Kolmogorov-Smirnov statistics. The result of the data normality test can be seen in Table 2. All the variables have the KolmogorovSmirnov $Z$-statistics with the probability values higher than $5 \%$. Based on these results, it can be concluded that all data used in this study are normally distributed.

Table 2. Data normality test results

\begin{tabular}{c|c|c}
\hline Description & $\begin{array}{c}\text { Kolmogorov- } \\
\text { Smirnov Z-statistics }\end{array}$ & $\begin{array}{c}\text { Probability } \\
\text { value }\end{array}$ \\
\hline Residual values & 0.411 & 0.954 \\
\hline
\end{tabular}

Glejser test was performed to test whether there is heteroscedasticity in the regression model or not. The Glejser test been done by regressing all independent variables toward absolute residuals. The result of Glejser test can be seen in Table 3. None of $t$-statistics has the probability value exceeding $5 \%$. So it can be concluded that no heteroscedasticity was found in the model.

Table 3. Glejser test results

\begin{tabular}{l|c:c}
\hline \multicolumn{1}{c}{ Variable } & t-statistics & Probability value \\
\hline ROA & 0.574 & 0.565 \\
\hline Asset structure & 0.572 & 0.567 \\
\hline Ln Size & 1.159 & 0.249 \\
\hdashline Ln Price & 0.111 & 0.911 \\
\hline
\end{tabular}

Note: Dependent variable is absolute residual.

Durbin-Watson test was performed to test whether there is autocorrelation in the model or not. The model produces the DW value of 2.103. Because 
the DW value is between 1.5 and 2.5 , so no autocorrelation was found in the model. The multicollinearity test was conducted by using the VIF value, if the VIF value is more than ten so it can be concluded that there is no multicollinearity. Based on the result shown in Table 4, all VIF values do not exceed ten, so no multicollinearity was found.

Table 4. Multicollinearity test results

\begin{tabular}{l|c}
\hline \multicolumn{1}{c|}{ Variable } & VIF \\
\hline ROA & 1.387 \\
\hdashline Asset structure & 2.368 \\
\hline Ln Size & 2.589 \\
\hline Ln Price & 5.697 \\
\hline
\end{tabular}

\subsection{Chow test and Hausman test}

The Chow test has been conducted to test whether the best model was the common effect model (CEM)/OLS or fixed effect model (FEM). The cross-section Chi-square is 1.369 , which is not significant at $5 \%$ level of significance. This result shows that the proper model is CEM/OLS. Based on this result, the Hausman test is not necessary. The Hausman test is only necessary if the Chow test result shows that the proper model is FEM, and the Hausman test is done to confirm it.

\subsection{Multiple regression result}

Based on the result of classical assumption tests, it can be concluded that the regression model was able to fulfill the classical assumptions. Based on the analysis of using multiple regression techniques, the results can be seen in Table 5 .

Table 5. Result of regression analysis

\begin{tabular}{l|c|c|c}
\hline Variable & $\begin{array}{c}\text { Unstandardized } \\
\text { coefficient }\end{array}$ & $\begin{array}{c}\text { Standardized } \\
\text { coefficient }\end{array}$ & $t$-value \\
\hline Constant & -3.298 & - & -0.412 \\
\hline ROA & -0.079 & 0.181 & $-2.033^{*}$ \\
\hline Asset & 2.154 & 0.163 & $5.541^{* *}$ \\
structure & -0.281 & 0.033 & -0.982 \\
\hline Ln Size & 0.499 & 0.029 & 0.158 \\
\hline Ln Price & & & \\
\hline
\end{tabular}

Notes: F-value: $12.995^{* *}, R$-square: $0.271, *$ significant at $\alpha=5 \%$,** significant at $\alpha=1 \%$.

The dependent variable is $D E R$.

Based on the results of the regression analysis, the regression equation can be formulated as follows:

$$
\begin{aligned}
& D E R=-3.298-0.079 R O A+ \\
& +4.154 \text { Asset structure }- \\
& -0.281 \text { Ln Size }+0.499 \operatorname{Ln} \text { Price }+e .
\end{aligned}
$$

$R O A$, as the independent variable, has a negative regression coefficient of 0.079 , which is significant at $\alpha=5 \%$. Therefore, $H 1$ stating that profitability has a negative effect on capital structure is supported. This supports various previous studies by Al-Ani and Al-Amri (2015), Dhingra and Dev (2016), Haron et al. (2013), Hermuningsih (2013), Nijenhuis (2013), Nnadi (2016), Serghiescu and Văidean (2014). This finding shows that higher profitability will lead to lower company's debt. The higher profitability will increase the retained earnings, and the company prefers to use internal funding over the external funding. This finding supports the pecking order theory. The ROA coefficient is -0.079 , whish means if $R O A$ increasing $1 \%$, the $D E R$ will be 0.079 lower, by assuming other variables constant.

Ln Size, as the independent variable, has a negative regression coefficient of 0.281 . However, it does not affect the capital structure significantly. Therefore, $\mathrm{H} 2$ stating that firm size has a positive effect on capital structure is not supported. This finding does not support Onofrei et al. (2015) and Handoo and Sharma (2014). Also, this finding does not support the trade-off theory introduced by Kraus and Litzenberger (1973).

The asset structure, as the independent variable, has a positive regression coefficient value of 2.154 , which is significant at $\alpha=1 \%$. This indicates that $\mathrm{H} 3$ stating that asset structure has a positive effect on capital structure is supported. This finding is consistent with the results of Handoo and Sharma (2014) and Nnadi (2016) who found the positive effect of asset structure on the capital structure. This finding supports the trade-off theory, which argues that companies with large assets will have a larger DER because they have assets as part of their collateral. They will also be able to obtain large amounts of debt because they are expected to have better access to the external fund sources compared to small companies. The asset structure coefficient of 2.154 means if asset structure increasing 1, the $D E R$ will 2.154 higher, by assuming other variables as constant. 
$L n$ Price (coal price variable (Price)), as the independent variable, has a positive regression coefficient value of 0.499 , but it does not affect the capital structure significantly. Therefore, $\mathrm{H} 4$ stating that coal prices have a positive effect on capital structure is not supported. This does not support the results by Handoo and Sharma (2014), Karadeniz et al. (2009), Nhung et al. (2017), Nnadi (2016). This finding does not support the trade-off theory. This could happen because the company's investment in coal mining was very large, making the capital structure not depend on the price of the commodity, but rather on the sustainability of its business.
The independent variable with the greatest influence on the capital structure is the $R O A$ variable because it has the largest standardized coefficient value. This is very reasonable with reference to the pecking order theory, which emphasizes that companies will be more concerned with internal than external funding. Furthermore, the ability of all independent variables to explain the amount of variation in the dependent variable is $27.1 \%$, and the rest is explained by other variables that are not included in the research model.

\section{CONCLUSION}

This study aims to examine the variables influencing the capital structure of coal mining companies listed on the IDX. In this study, the capital structure is represented by the debt to equity ratio. From four hypotheses formulated, only two hypotheses can be accepted, which is $H 1$ and $H 3$. H1 stating that profitability has a negative effect on capital structure is supported, while $H 3$ stating that asset structure has a positive effect on capital structure is supported.

The results of this study indicated that of all the independent variables studied, it turned out that only two independent variables had a significant influence on the capital structure of coal mining companies, namely the profitability variable represented by $R O A$ and asset structure variable. Profitability affects the capital structure negatively. This study also finds that $R O A$ has a dominant effect on the DER, and the coefficient of determination is $26.8 \%$, which shows the ability of all independent variables to explain the amount of variation in the dependent variable of $26.8 \%$.

This finding supports the pecking order theory, which states that companies will tend to use internal funds before using external funds. This also shows that companies with high profitability will tend to use funding through internal sources, namely using profits rather than debt when they need funding. The influence of the asset structure is positive, which indicated that the higher the fixed assets of the company, the higher the asset structure.

The results of this study can be useful as a reference in the financial literature, especially literature regarding the company's capital structure. Based on the findings, the company managers need to pay attention to the profitability and asset structure of the companies they manage. The managers may start considering to re-balance the use of external funds if the profitability level increases. Further, they also need to maintain the company's asset structure and balance its fixed assets so that the capital structure is well maintained.

For future researchers interested in the studies in the same field, it is advisable to perform a study using samples taken from the regional stock exchange, such as stock exchanges located in ASEAN countries, by using dynamic panel data. 


\section{REFERENCES}

1. Abdur Rouf, M. (2015). Capital Structure and Firm Performance of Listed Non-Financial Companies in Bangladesh. The International Journal of Applied Economics and Finance, 9(1), 25-32. https://doi.org/10.3923/ ijaef.2015.25.32

2. Abor, J. (2008). Determinants of the Capital Structure of Ghanaian Firms. AERC Research Paper, 178. Retrieved from https://www. africaportal.org/documents/5813/ RP176.pdf

3. Al-Ani, M. K., \& Al-Amri, M. S. (2015). The Determinants of Capital Structure: An Empirical Study of Omani Listed Industrial Companies. Business: Theory and Practice, 16(2), 159-167. https:// doi.org/10.3846/btp.2015.471

4. Baker, M., \& Wurgler, J. (2002). Market Timing and Capital Structure. Journal of Finance, 57(1), 1-32. https://doi. org/10.1111/1540-6261.00414

5. Brigham, E. F., \& Houston, J. F. (2012). Fundamentals of Financial Management. Cengage Learning.

6. Chirinko, R. S., \& Singha, A. R. (2000). Testing Static Tradeoff Against Pecking Order Models of Capital Structure: a Critical Comment. Journal of Financial Economics, 58, 417-425. https:// doi.org/10.1016/S0304405X(00)00078-7

7. Dananti, K., Cahjono, M. P., \& Mujiyono. (2018). The Best Indicator of Capital Structure to Predict Firm's Performance. Review of Integrative Business and Economics Research, 6(4), 317-326.

8. Dhingra, R., \& Dev, K. (2016). Determinants of Capital Structure-A Study of Oil Industry in India. International Journal of Engineering and Management Research, 6(1), 35-42. Retrieved from http://www.ijemr.net/DOC/ DeterminantOfCapitalStructureAStudyOfOilIndustryInIndia. pdf

9. Enakirerhi, L. I., \& Chijuka, M. I. (2016). The Determinants of Capital Structure of FTSE 100
Firms in the UK: A Fixed Effect

Panel Data Approach. Research Journal of Finance and Accounting, 7(13), 56-73. Retrieved from https://pdfs.semanticscholar. org/06a1/e968ecd9c55484b1dcedff3e7c24349e8df6.pdf

10. Eriotis, N., Vasiliou, D., \& Ventoura-Neokosmidi, Z. (2007). How firm characteristics affect capital structure: an empirical study. Managerial Finance, 33(5), 321-331. https://doi. org/10.1108/03074350710739605

11. Ernayani, R., \& Robiyanto, R. (2016). The effect of the cash flows, gross profit and company size on Indonesian stock returns (a study on the chemical and basic industry companies during the periods of 2009-2014). International Journal of Applied Business and Economic Research, 14(3), 1697-1709. Retrieved from https://papers.ssrn.com/sol3/papers.cfm?abstract_id=2795657

12. Eviani, A. D. (2015). Pengaruh Struktur Aktiva, Pertumbuhan Penjualan, Dividen Payout Ratio, Likuiditas dan Profitabilitas Terhadap Struktur Modal. Jurnal Akuntansi dan Sistem Teknologi Informasi, 11(2), 194-202. Retrieved from http://ejurnal. unisri.ac.id/index.php/Akuntansi/ article/view/1137

13. Fatoni, Y., Paramu, H., \& Utami, E. S. (2013). Determinan Struktur Modal Pada Perusahaan Pertambangan Sub Sektor Batubara dan Non Batubara yang Listed di Bursa Efek Indonesia. Jurnal Bisnis dan Ekonomi, 20(1), 1-11. Retrieved from https://www. unisbank.ac.id/ojs/index.php/fe3/ article/view/2342

14. Gómez, A., Castro, G. Á., \& Ortega, M. F. (2016). Determinants of leverage in mining companies, empirical evidence for Latin American countries. Contaduría y Administración, 61(1), 2640. https://doi.org/10.1016/j. cya.2015.09.010

15. Hair, J. F., Black, W. C., Babin, B. J., \& Anderson, R. E. (2009).
Multivariate Data Analysis (7th ed.). Pearson.

16. Handoo, A., \& Sharma, K. (2014). A study on determinants of capital structure in India. IIMB Management Review, 26(3), 170182. https://doi.org/10.1016/j. iimb.2014.07.009

17. Handriani, E., \& Robiyanto, R. (2018a). Corporate Finance and Firm Value in The Indonesian Manufacturing Companies. International Research Journal of Business Studies, 11(2), 113-127. https://doi.org/10.21632/irjbs.11.2.113-127

18. Handriani, E., \& Robiyanto, R. (2018b). Investment Opportunity and Industrial Growth in Indonesia. International Journal of Business and Society, 19(2), 295-312.

19. Handriani, E., \& Robiyanto, R. (2019). Institutional ownership, independent board, board size, and firm performance: evidence from Indonesia. Contaduría y Administración, 64(3), 1-16. http://dx.doi.org/10.22201/ fca.24488410e.2018.1849

20. Hang, M., Geyer-Klingeberg, J., Rathgeber, A. W., \& Stöckl, S. (2018). Measurement matters A meta-study of the determinants of corporate capital structure. The Quarterly Review of Economics and Finance, 68, 211-225. https:// doi.org/10.1016/j.qref.2017.11.011

21. Haron, R., Ibrahim, K., Nor, F. M., \& Ibrahim, I. (2013). Dynamic Adjustment towards Target Capital Structure: Thailand Evidence. Jurnal Pengurusan, 39, 73-82.

22. Harris, M., \& Raviv, A. (1991). The Theory of Capital Structure. Journal of Finance, 46(1), 297-355. https://doi. org/10.1111/j.1540-6261.1991. tb03753.x

23. Haryanto, S. (2016). Determinan Permodalan Bank melalui Profitabilitas, Risiko, Ukuran Perusahaan, Efisiensi dan Struktur Aktiva. Jurnal Ekonomi dan Bisnis, 19(1), 117-138. https://doi. org/10.24914/jeb.v19i1.483 
24. Hermuningsih. (2013). Pengaruh Profitabilitas, Growth Opportunity, Struktur Modal Terhadap Nilai Perusahaan Pada Perusahaan Publik di Indonesia. Buletin Ekonomi Moneter dan Perbankan, 16(2), 127-148. https://doi. org/10.21098/bemp.v16i2.27

25. Hersugondo, S., Robiyanto, R., Wahyudi, S., \& Muharam, H. (2015). The World Oil Price Movements and Stock Returns in Several Southeast Asia's Capital Markets. International Journal of Applied Business and Economic Research, 13(2), 527-534.

26. Huang, R., \& Ritter, J. R. (2004). Testing the Market Timing Theory of Capital Structure (Working Paper). Retrieved from https://www3. nd.edu/ pschultz/HuangRitter.pdf

27. Joni, \& Lina. (2010). Faktor-Faktor Yang Mempengaruhi Struktur Modal. Jurnal Bisnis dan Akuntansi, 12(2), 81-96. Retrieved from https://www.researchgate.net/ publication/322911911_FAKTORFAKTOR_YANG_MEMPENGARUHI_STRUKTUR_MODAL_ PADA_PERUSAHAAN_MANUFAKTUR_YANG_TERDAFTAR_ DI_BEI

28. Karadeniz, E., Kandir, S. Y., Balcilar, M., \& Onal, Y. B. (2009). Determinants of capital structure: evidence from Turkish lodging companies. International Journal of Contemporary Hospitality Management, 21(5), 594-609. https://doi. org/10.1108/09596110910967827

29. Kayedi, S. I., Ghahramanizady, M., \& Jafarzadeh, A. (2013). Study the Effect of Sales Growth on the Determinants of Capital Structure of Listed Companies in Tehran Stock Exchange. Technical Journal of Engineering and Applied Sciences, 3(15), 306-311.

30. Kesuma, A. (2009). Analisis Faktor yang Mempengaruhi Struktur Modal Serta Pengaruhnya Terhadap Harga Saham Perusahaan Real Estate yang Go Public di Bursa Efek Indonesia. Jurnal Manajemen and Kewirausahaan, 11(1), 38-45. Retrieved from http:// jurnalmanajemen.petra.ac.id/index. $\mathrm{php} / \mathrm{man} /$ article/view/17743
31. Kock, N. (2018). Chapter 1 Minimum Sample Size Estimation in PLS-SEM: An Application in Tourism and Hospitality Research. In Applying Partial Least Squares in Tourism and Hospitality Research (pp. 1-16).

32. Kock, N., \& Hadaya, P. (2018). Minimum sample size estimation in PLS-SEM: The inverse square root and gamma-exponential methods. Information Systems Journal, 28(1), 227-261. https://doi. org/10.1111/isj.12131

33. Kraus, A., \& Litzenberger, R. H. (1973). A State-Preference Model of Optimal Financial Leverage. The Journal of Finance, 28(4), 911-922. https://doi. org/10.2307/2978343

34. Kumar, S., Colombage, S., \& Rao, P. (2017). Research on capital structure determinants: a review and future directions. International Journal of Managerial Finance, 13(2), 106132. https://doi.org/10.1108/IJMF09-2014-0135

35. Kurronen, S. (2018). Natural resources and capital structure. Economic Systems, 42(3), 385-396. https://doi.org/10.1016/j.ecosys.2017.12.002

36. Maneerattanarungrot, C., \& Donkwa, K. (2018). Capital structure affecting firm value in Thailand. ABAC Journal, 38(2), 133-146.

37. Margaretha, F., \& Rizki, R. A. (2010). Faktor-Faktor Yang Mempengaruhi Struktur Modal Pada Industri Manufaktur di Bursa Efek Indonesia. Jurnal Bisnis dan Akuntansi, 12(2), 119130.

38. Michalski, G., Blendinger, G., Rozsa, Z., Cierniak-Emerych, A., Svidronova, M., Buleca, J., \& Bulsara, H. (2018). Can We Determine Debt To Equity Levels In Non-Profit Organisations? Answer Based On Polish Case. Engineering Economics, 29(5), 526535. http://dx.doi.org/10.5755/j01. ee.29.5.19666

39. Modigliani, F., \& Miller, M. H. (1958). The Cost of Capital, Corporation Finance and The
Theory of Investment. American Economic Review, 48(13), 261-297.

40. Murhadi, W. R. (2011).

Determinan Struktur Modal:

Studi di Asia Tenggara. Jurnal

Manajemen dan Kewirausahaan, 13(2), 91-98. https://doi. org/10.9744/jmk.13.2.91-98

41. Myers, S. C., \& Majluf, N. S. (1984). Corporate financing and investment decisions when firms have information that investors do not have. Journal of Financial Economics, 13(2), 187-221. https://doi.org/10.1016/0304405X(84)90023-0

42. Nhung, N. T. P., Lien, N. P., \& Hang, D. T. T. (2017). Analyze the Determinants of Capital Structure for Vietnamese Real Estate Listed Companies. International Journal of Economics and Financial Issues, 7(4), 270-282.

43. Nijenhuis, K. T. (2013). Important factors in determining the capital structure of a company. Empirical evidence from Dutch companies (Thesis). University of Twente. Retrieved from https://essay.utwente.nl/64528/1/Master\%20thesis, $\% 20$ Important $\% 20$ factors $\% 20$ in $\% 20$ determining $\% 20$ the $\% 20$ capital $\% 20$ structure $\% 20$ of $\% 20$ a $\% 20$ company.\%20Empirical $\% 20$ evidence\%20from\%20Dutch\%20companies.pdf

44. Nnadi, M. (2016). Accounting Factors Affecting the Capital Structure in the Asian Economic Community. International Journal of Accounting Research, 5(1), 1-9. Retrieved from https://www.researchgate.net/ publication/315060953_Accounting_Factors_Affecting_the Capital_Structure_in_the_Asian_ Economic_Community

45. Nugroho, A. S. (2006). Analisis Faktor-Faktor yang Mempengaruhi Struktur Modal Perusahaan Properti yang Go Public di Bursa Efek Jakarta untuk Periode Tahun 1994-2004 (Master of Management Master Thesis). Universitas Diponegoro, Semarang, Indonesia. Retrieved from http://eprints. undip.ac.id/15389/

46. Onofrei, M., Tudose, M. B. Durdureanu, C., \& Anton, 
S. G. (2015). Determinant Factors of Firm Leverage: An Empirical Analysis at Iasi County Level. Procedia Economics and Finance, 20, 460-466. https:// doi.org/10.1016/s2212 5671(15)00097-0

47. Park, H. M. (2011). Practical Guides To Panel Data Modeling: A Step by Step Analysis Using Stata. Retrieved from http://www.iuj. ac.jp/faculty/kucc625

48. Popovic, Z., \& Paunovic, M. (2018). The Dependence of the Cost of Capital on Degree of Diversification. Montenegrin Journal of Economics, 14(1), 53-67. https://doi.org/10.14254/18005845/2018.14-1.4

49. Putra, A. R., \& Robiyanto, R. (2019). The effect of commodity price changes and USD/IDR exchange rate on Indonesian mining companies' stock return. Jurnal Keuangan dan Perbankan, 23(103-115). https://doi. org/10.26905/jkdp.v23i1.2084

50. Robiyanto, R. (2018a). The dynamic correlation between ASEAN-5 stock markets and world oil prices. Jurnal Keuangan dan Perbankan, 22(2), 198-210. https://doi.org/10.26905/jkdp. v22i2.1688

51. Robiyanto, R. (2018b). The Effect of Gold Price Changes, USD/
IDR Exchange Rate Changes and Bank Indonesia (BI) Rate on Jakarta Composite Index (JCI)'s Return and Jakarta Islamic Index (JII)'s Return. Jurnal Manajemen dan Kewirausahaan, 20(1), 45-52. https://doi.org/10.9744/ jmk.20.1.45-52

52. Robiyanto, R. (2018c). Gold VS Bond: What Is the Safe Haven for the Indonesian and Malaysian Capital Market? Gadjah Mada International Journal of Business, 20(3), 277-302. https://doi. org/10.22146/gamaijb.27775

53. Sahabuddin, Z. A. (2017). Asset Structure Impact on Capital Structure of Capital Market-Listed Firms in Indonesia and Malaysia. Jurnal Keuangan dan Perbankan, 21(3), 376-386. https://doi. org/10.26905/jkdp.v21i3.1312

54. Santos, L. A., \& Barrios, E. B. (2011). Small Sample Estimation in Dynamic Panel Data Models: A Simulation Study. Open Journal of Statistics, 01(02), 58-73. https:// doi.org/10.4236/ojs.2011.12007

55. Sartono, A. (2001). Manajemen Keuangan Teori dan Aplikasi. Yogyakarta, Indonesia: BPFE UGM.

56. Serghiescu, L., \& Văidean, V.-L. (2014). Determinant Factors of the Capital Structure of a Firm- an Empirical Analysis. Procedia Economics and Finance, 15, 1447 1457. https://doi.org/10.1016/ s2212-5671(14)00610-8

57. Stiglitz, J. E. (1973). Taxation, corporate financial policy, and the cost of capital. Journal of Public Economics, 12(1), 1-34. https://doi.org/10.1016/00472727(73)90008-X

58. Suarez, P. (2016). Determinants of Capital Structure for Listed Companies in the Colombian Industrial Sector. Catalyst, 13(2), 33-45. Retrieved from https://so01. tci-thaijo.org/index.php/hbds/ article/view/178610

59. Utomo, M. N., Wahyudi, S., Muharam, H., \& Taolin, M. L. (2018). Strategy to improve firm performance through operational efficiency commitment to environmental friendlines: Evidence from Indonesia. Organizations and Markets in Emerging Economies, 9(1), 6285. https://doi.org/10.15388/ omee.2018.10.00004

60. Uzliawati, L., Yuliana, A., Januarsi, Y., \& Santoso, M. I. (2018). Optimisation of Capital Structure and Firm Value. European Research Studies Journal, 21(2), 705-713. Retrieved from https:// ideas.repec.org/a/ers/journl/vxxiy2018i2p705-713.html 